FACTA UNIVERSITATIS

Series: Mechanical Engineering Vol. 15, Nº 3, 2017, pp. 467 - 477

https://doi.org/10.22190/FUME160812011S

Original scientific paper

\title{
FORCED CONVECTION DRYING OF INDIAN GROUNDNUT: AN EXPERIMENTAL STUDY
}

UDC 662.6

\author{
Ravinder Kumar Sahdev ${ }^{1}$, Mahesh Kumar², Ashwani Kumar Dhingra ${ }^{1}$ \\ ${ }^{1}$ Mechanical Engineering Department, Maharshi Dayanand University, India \\ ${ }^{2}$ Mechanical Engineering Department, \\ Guru Jambheshwar University of Sciences \& Technology, India
}

\begin{abstract}
In this paper, convective and evaporative heat transfer coefficients of the Indian groundnut were computed under indoor forced convection drying (IFCD) mode. The groundnuts were dried as a single thin layer with the help of a laboratory dryer till the optimum safe moisture storage level of $8-10 \%$. The experimental data were used to determine the values of experimental constants $C$ and $n$ in the Nusselt number expression by a simple linear regression analysis and consequently, the convective heat transfer coefficient (CHTC) was determined. The values of CHTC were used to calculate the evaporative heat transfer coefficient (EHTC). The average values of CHTC and EHTC were found to be $2.48 \mathrm{~W} / \mathrm{m}^{2}{ }^{\circ} \mathrm{C}$ and $35.08 \mathrm{~W} / \mathrm{m}^{2}{ }^{\circ} \mathrm{C}$, respectively. The experimental error in terms of percent uncertainty was also estimated. The experimental error in terms of percent uncertainty was found to be $42.55 \%$. The error bars for convective and evaporative heat transfer coefficients are also shown for the groundnut drying under IFCD condition.
\end{abstract}

Key Words: Groundnut/peanut, Convective Heat Transfer Coefficient, Evaporative Heat Transfer Coefficient, Indoor Forced Convection Drying

\section{INTRODUCTION}

Groundnut or peanut (Arachis hypogaea) is a perishable oilseed crop grown in tropic and sub-tropic countries [1]. It is rich in proteins $(20-50 \%)$ and edible oil $(40-50 \%)$ which makes it very popular all over the world [2]. It is also known by various names such as monkey nut, wonder nut, earth nut, cashew nut of poor men and so on [3]. It came into existence in India in the $16^{\text {th }}$ century. The worldwide production of groundnuts has

Received August 12, 2016 / Accepted June 08, 2017

Corresponding author: Ravinder Kumar Sahdev

Maharshi Dayanand University, Rohtak - 124001, Haryana, India

E-mail: ravindersahdev1972@gmail.com 
reached about 40 million tons [4]. It is grown on 24 million hectares land throughout the world [4]. China with 16.70 metric million tons is the largest groundnut producing country followed by India with a production of 5 metric million tons [4]. In India about three quarters of groundnut is harvested in the Kharif season (June - September) and the remaining quarter in the Rabi season (November - March). Indian groundnut is famous for its flavor, aroma and crunchiness. Export of Indian groundnuts has reached the record of 7 Lac tons in $2014-2015$ [5].

Drying of agricultural products is the simplest traditional food preservation method which involves the removal of the water present in the product to stop fungus or bacteria growth [6]. Groundnuts, just after being dug out from the ground, are required to dry to their safe moisture content of $8-10 \%$. In the developing countries, poor farmers dry groundnuts under open sun drying (OSD) mode which takes four to five days to dry the groundnuts to their safe moisture level. Although the OSD is unquestionably the cheapest post-harvest method, it involves many disadvantages such as deterioration of products due to dust, dirt, uncontrolled heating and discoloring of products because of Ultra-Violet rays, animals, microorganisms and so on. Post-harvest losses of the agricultural products are estimated to be about $30-40 \%$ due to an improper method of drying [7-8]. Moreover, farmers are also lacking behind with the better drying facilities. Hence, the need is felt to adopt such a method which gives continuous and controlled drying.

The convective heat transfer coefficient (CHTC) for the drying of groundnut is an important and critical parameter required for the proper design of a dryer. It is governed by the temperature difference between groundnut surface and air, and the physical properties of the humid air which surrounds the groundnut surface. The researchers who have worked on the drying of various commodities under the forced convection drying mode are summarized in Table 1. Some authors who have also studied the drying of groundnuts under the forced mode are summarized in Table 2.

Table 1 Summary of drying of various commodities

\begin{tabular}{|c|c|c|c|c|c|}
\hline $\begin{array}{l}\text { S. } \\
\text { No. }\end{array}$ & Researcher & Ref. & Commodity & $\begin{array}{l}\text { Mode of } \\
\text { drying }\end{array}$ & Conclusion/Remarks \\
\hline 1 & $\begin{array}{l}\text { Akpinar } \\
\text { (2004) }\end{array}$ & [9] & $\begin{array}{l}\text { Apple, strawberry, } \\
\text { eggplant, garlic, } \\
\text { mulberry, onion, } \\
\text { pumpkin, potato }\end{array}$ & $\begin{array}{l}\text { Indoor forced } \\
\text { convection } \\
\text { drying } \\
\text { (IFCD) }\end{array}$ & $\begin{array}{l}\text { The value of CHTC was reported to } \\
\text { lie within the range of } \\
0.64-7.12 \mathrm{~W} / \mathrm{m}^{2}{ }^{\circ} \mathrm{C}\end{array}$ \\
\hline 2 & $\begin{array}{l}\text { Kumar et al. } \\
\text { (2011) }\end{array}$ & {$[10]$} & Papad & $\begin{array}{l}\text { OSD and } \\
\text { IFCD }\end{array}$ & $\begin{array}{l}\text { The values of CHTC were found to be } \\
3.54 \mathrm{~W} / \mathrm{m}^{2 \circ} \mathrm{C} \text { and } 1.56 \mathrm{~W} / \mathrm{m}^{2 \circ} \mathrm{C} \text { under } \\
\text { OSD and IFCD modes, respectively }\end{array}$ \\
\hline 3 & $\begin{array}{l}\text { Anwar and } \\
\text { Singh (2012) }\end{array}$ & [11] & Indian gooseberry & IFCD & $\begin{array}{l}\text { The values of CHTC were observed } \\
\text { to vary from } 18.67 \text { to } 116.55 \mathrm{~W} / \mathrm{m}^{2}{ }^{\circ} \mathrm{C}\end{array}$ \\
\hline 4 & $\begin{array}{l}\text { Sahdev et al. } \\
\text { (2012) }\end{array}$ & [12] & Vermicelli & IFCD & $\begin{array}{l}\text { The value of CHTC was reported to } \\
\text { vary from } 0.98 \text { to } 1.10 \mathrm{~W} / \mathrm{m}^{20} \mathrm{C}\end{array}$ \\
\hline 5 & $\begin{array}{l}\text { Sahdev et al. } \\
\text { (2013) }\end{array}$ & [13] & Corn kernels & IFCD & $\begin{array}{l}\text { The value of CHTC was found to vary } \\
\text { from } 1.02 \text { to } 1.04 \mathrm{~W} / \mathrm{m}^{2}{ }^{\circ} \mathrm{C} \text {. }\end{array}$ \\
\hline 6 & Kumar (2014) & [14] & Khoa & IFCD & $\begin{array}{l}\text { The values of CHTC and evaporative } \\
\text { heat transfer coefficient (EHTC) } \\
\text { were observed to vary } \\
\text { from } 1.93 \text { to } 2.51 \mathrm{~W} / \mathrm{m}^{2}{ }^{\circ} \mathrm{C} \\
\text { and } 1.94 \text { to } 2.49 \mathrm{~W} / \mathrm{m}^{2} \mathrm{C} \text {, respectively }\end{array}$ \\
\hline
\end{tabular}


Table 2 Summary of groundnuts drying under forced mode

\begin{tabular}{ccccc}
\hline $\begin{array}{c}\text { S. } \\
\text { No. }\end{array}$ & Researcher & Ref. & Mode of drying & Conclusion/Remarks \\
\hline 1 & $\begin{array}{c}\text { Ahmed et al. } \\
(1967)\end{array}$ & {$[15]$} & $\begin{array}{c}\text { OSD and } \\
\text { accelerating drying } \\
\text { Trailer drying }\end{array}$ & Carried out the Comparative study \\
Presented single and double trailer \\
drying
\end{tabular}

The above-listed literature leads to observation that different agricultural products have been dried under IFCD conditions to reduce the drying time and increase the quality. The values of CHTC and EHTC for the drying of various products under IFCD mode are reported to vary from 0.16 to $116.55 \mathrm{~W} / \mathrm{m}^{2}{ }^{\circ} \mathrm{C}$ and 1.94 to $2.49 \mathrm{~W} / \mathrm{m}^{2}{ }^{\circ} \mathrm{C}$, respectively. Although groundnuts/peanuts have also been dried by different artificial and mechanical dryer to improve the quality and storage life. Studies to evaluate the important parameters such as CHTC and EHTC for designing a dryer for groundnut drying have not been found. Therefore, the present study has been undertaken to determine the CHTC and EHTC of groundnut drying under IFCD mode. This study would be helpful in designing a better dryer for drying groundnut to its safe moisture storage level. 


\section{MATERIALS AND METHODS}

\subsection{Experimental set-up}

The groundnut sample of $180 \mathrm{~g}$ was kept in a wire mesh tray (rectangular shape of $0.15 \times 0.25 \mathrm{~m}^{2}$ size) over the digital weighing balance of $6 \mathrm{~kg}$ capacity (least count $=0.1 \mathrm{~g}$ ). A heat convector (Model FH-812T, Usha Shriram, made in India) was used for blowing hot air over the groundnut surface. The temperature of groundnut surface $\left(T_{g}\right)$ was measured by calibrated copper constantan thermocouples connected to a 12-channel digital temperature indicator (least count $=0.1{ }^{\circ} \mathrm{C}$ ). The thermocouples were calibrated with respect to the ZEAL thermometer which gives accurate readings. Relative humidity $(\gamma)$ and temperature of exit air $\left(T_{e}\right)$ was measured by a digital hygrometer (Lutron - HT 315, least count: $0.1 \%$ RH and $0.1{ }^{\circ} \mathrm{C}$ temperature). Air velocity $\left(V_{a}\right)$ over the groundnut surface was measured with a digital anemometer (Lutron, AM - 4201, Taiwan, least count: $0.1 \mathrm{~m} / \mathrm{s}$, accuracy $\pm 2 \%$ on the full scale range of $0.2-30.0 \mathrm{~m} / \mathrm{s}$ ). The schematic view and photograph of the experimental set up are shown in Figs. 1 and 2, respectively.

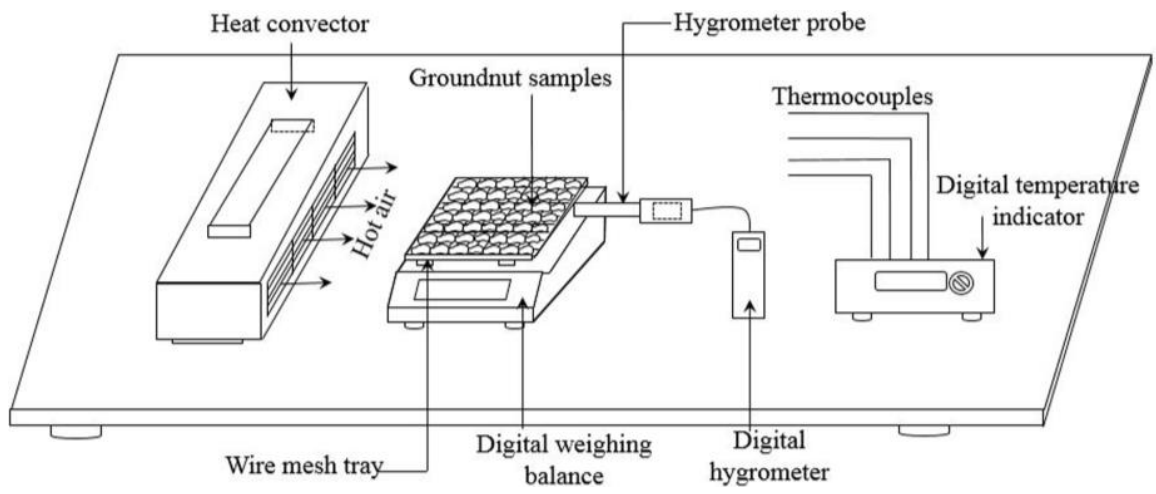

Fig. 1 Schematic view of the experimental set up under IFCD Mode

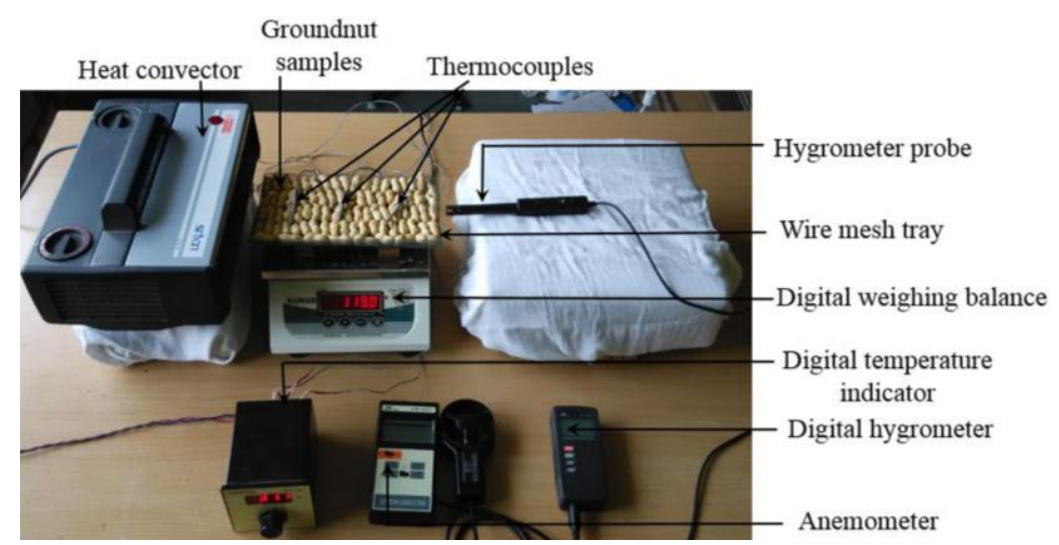

Fig. 2 Experimental set up under IFCD Mode 


\subsection{Sample preparation and experimental procedure}

Fresh groundnuts were purchased directly from the farmer and cleaned to remove immature and broken pods. Groundnuts were remoistened by soaking in water for 12 hours. Then the samples were conditioned in shed for one hour so that the extra moisture was removed. Then the groundnut sample was used for experimentation.

The experiment was performed in February, 2016 in the climatic conditions of Rohtak, India ( $28^{\circ} 54^{\prime} 0^{\prime}$ ' $\mathrm{N} 76^{\circ} 34^{\prime} 0^{\prime}$ 'E). The groundnut sample in a thin layer was kept in a wire mesh tray of size $0.25 \times 0.15 \mathrm{~m}^{2}$ directly over the digital weighing balance. The difference in weight between two consecutive $30 \mathrm{~min}$. time interval observed readings directly gave the moisture evaporation during the observed time interval. The $30 \mathrm{~min}$. data for the moisture removal, groundnut surface and ambient temperatures, relative humidity and temperature just above the groundnut surface were recorded. The groundnut sample was dried to its optimum safe moisture level of $8-10 \%$.

\subsection{Thermal modeling}

The CHTC under IFCD can be evaluated by using following Eq. [1]:

$$
N u=\frac{h_{c} X}{K_{v}}=C(\operatorname{RePr})^{n}
$$

where $N u$ is the Nusselt number, $h_{c}$ is the convective heat transfer coefficient, $X$ is the characteristic dimension, $K_{v}$ is the thermal conductivity of the humid air, $C$ and $n$ are the experimental constants, $R e$ is the Reynolds number and $P r$ is the Prandtl number. From Eq. (1) one can write:

$$
h_{c}=\frac{K_{v}}{X} C(\operatorname{RePr})^{n}
$$

The rate of heat utilized to evaporate moisture, $Q_{e}$, is given by Eq. (3) [34]:

$$
Q_{e}=0.016 h_{c}\left[P\left(T_{g}\right)-\gamma P\left(T_{e}\right)\right]
$$

where $P\left(T_{g}\right)$ and $P\left(T_{e}\right)$ are partial vapor pressures at temperatures $T_{g}$ and $T_{e}$, respectively.

Substituting the value of CHTC i.e. $h_{c}$ from Eq. (2), Eq. (3) becomes

$$
Q_{e}=0.016 \frac{K_{v}}{X} C(\operatorname{RePr})^{n}\left[P\left(T_{g}\right)-\gamma P\left(T_{e}\right)\right]
$$

The moisture evaporated, $m_{e v}$, is determined by dividing Eq. (4) by latent heat of vaporization, $\lambda$, and multiplying by tray area $A_{\text {tray }}$, and time interval, $t$.

$$
m_{e v}=\frac{Q_{e}}{\lambda} t A_{\text {tray }}=0.016 \frac{K_{v}}{X \lambda} C(\operatorname{RePr})^{n}\left[P\left(T_{g}\right)-\gamma P\left(T_{e}\right)\right] t A_{\text {tray }}
$$

Let

$$
\begin{gathered}
0.016 \frac{K_{v}}{X \lambda}\left[P\left(T_{g}\right)-\gamma P\left(T_{e}\right)\right] t A_{\text {tray }}=Z \\
\therefore \frac{m_{e v}}{Z}=C(\operatorname{RePr})^{n}
\end{gathered}
$$


Taking logarithm on both sides of Eq. (6), we get

$$
\ln \left[\frac{m_{e v}}{Z}\right]=\ln C+n \ln (\operatorname{RePr})
$$

Eq. (7) is the form of a linear equation:

$$
y=m x+c
$$

where $y=\ln \left[\frac{m_{e v}}{Z}\right], m=n, x=\ln (\operatorname{RePr}), \mathrm{c}=\ln C$. Thus, $C=e^{\mathrm{c}}$

The values of $m$ and $c$ in Eq. (8) are obtained by using simple linear regression formulae. The EHTC, $h_{e}$, is evaluated as [35]

$$
h_{e}=0.016 h_{c}\left[\frac{P\left(T_{g}\right)-\gamma P\left(T_{e}\right)}{T_{g}-T_{e}}\right]
$$

\subsection{Physical properties of the humid air}

The thermo-physical properties of the humid air, namely, thermal conductivity, $K_{v}$, dynamic viscosity, $\mu_{v}$, density, $\rho_{v}$, specific heat, $C_{v}$, and partial vapor pressure $P(T)$ were calculated for the mean temperature $T_{i}=\left[\left(T_{g}+T_{e}\right) / 2\right]$ by using the following Eqs. $(10-14)$ [36]:

$$
\begin{gathered}
K_{v}=0.0244+0.7673 \times 10^{-4} T_{i} \\
\mu_{v}=1.718 \times 10^{-5}+4.620 \times 10^{-8} T_{i} \\
C_{v}=999.2+0.1434 T_{i}+1.101 \times 10^{-4} T_{i}^{2}-6.7581 \times 10^{-8} T_{i}^{3} \\
\rho_{v}=\frac{353.44}{T_{i}+273.15} \\
P(T)=\exp \left[25.317-\frac{5144}{T+273.15}\right]
\end{gathered}
$$

\subsection{Experimental error and external uncertainty}

The experimental error was determined in terms of percent uncertainty (internal + external) for the mass of moisture evaporated. Eqs. (15) to (17) were used to calculate internal uncertainty [37]:

$$
U^{*}=\frac{\sqrt{\sigma_{1}^{2}+\sigma_{2}^{2}+\sigma_{3}^{2}+\ldots+\sigma_{n}^{2}}}{N}
$$

where $\sigma$ is the standard deviation and is by Eq. (16):

$$
\sigma=\sqrt{\frac{\sum\left(X_{i}-\overline{X_{i}}\right)}{N_{o}}}
$$


where $X_{i}$ is the moisture evaporated and $\left(X_{i}-X_{i}\right)$ is the deviation of the observations from the mean value, $N$ and $N_{o}$ are the number of sets and number of observations in each set respectively. The percent uncertainty was evaluated as:

$$
\% \text { internaluncertainty }=\frac{U^{*}}{\text { Average of total number of observations }} \times 100
$$

The external uncertainty is the least count of all the instruments.

\subsection{Computation technique}

The average of groundnut surface temperature $\left(T_{g}\right)$ and exit air temperature $\left(T_{e}\right)$ after the groundnut surface were determined at 30 minutes time interval for corresponding moisture evaporation. The physical properties of the humid air were evaluated for the mean temperature $\left[T_{i}=\left(T_{g}+T_{e}\right) / 2\right]$ using Eq. (10) to (14). These properties of the humid air and air velocity were used to calculate the Prandtl number $(\mathrm{Pr})$ and Reynolds number $(R e)$. The values of experimental constants $C$ and $n$ in Eq. (1) were determined by using the linear regression technique analysis, and hence the value of CHTC $\left(h_{c}\right)$ was evaluated. Then, the value of EHTC $\left(h_{e}\right)$ was calculated by using Equation (9).

\section{RESULTS AND DISCUSSION}

The experimental data obtained for groundnut drying under IFCD mode is given in Table 3. The data given in Table 3 were used to determine the values of the experimental constant ' $C$ ' and exponent ' $n$ ' in the Nusselt number expression by simple linear regression. Then the values of constants $\mathrm{C}$ and $\mathrm{n}$ in Eq. (2) were used to evaluate the CHTC $\left(h_{c}\right)$. Further, the value of EHTC $\left(h_{e}\right)$ was calculated by substituting the value of $h_{c}$ in Eq. (9). The computed values of constants $C$ and $n, h_{c}$, and $h_{e}$ for groundnut drying under IFCD are summarized in Table 4. The values of Reynolds Number $(R e)$ and Prandtl number $(P r)$ are also given. The product of $\operatorname{Re}$ and $\operatorname{Pr}$ were observed to be less than $10^{5}$, (i.e. $\operatorname{Re} P r \leq 10^{5}$ ). This indicated that the entire groundnut drying under IFCD mode lies within the laminar region [38].

Table 3 Experimental data for groundnut drying under IFCD condition

\begin{tabular}{ccccccc}
\hline $\begin{array}{c}\text { Drying time } \\
(\mathrm{min})\end{array}$ & $\begin{array}{c}T_{g} \\
\left({ }^{\circ} \mathrm{C}\right)\end{array}$ & $\begin{array}{c}T_{e} \\
\left({ }^{\circ} \mathrm{C}\right)\end{array}$ & $\begin{array}{c}m_{e v} \\
\times 10^{-3}(\mathrm{~kg})\end{array}$ & $\begin{array}{c}\gamma \\
(\%)\end{array}$ & $\begin{array}{c}R e \\
\times 10^{4}\end{array}$ & $\operatorname{Pr}$ \\
\hline 30 & 29.9 & 25.83 & 24.3 & 38.78 & 1.87 & 0.6982 \\
60 & 44.5 & 35.33 & 11.7 & 22.75 & 1.74 & 0.6963 \\
90 & 45.7 & 36.52 & 8.1 & 19.88 & 1.73 & 0.6961 \\
120 & 46.5 & 36.98 & 4.5 & 19.12 & 1.72 & 0.6960 \\
150 & 46.8 & 37.42 & 3.2 & 18.42 & 1.72 & 0.6959 \\
\hline
\end{tabular}

Table 4 Values of $C, n, h_{c}$, and $h_{e}$

\begin{tabular}{cccccc}
\hline$C$ & $n$ & $\begin{array}{c}h_{c} \\
\left(\mathrm{~W} / \mathrm{m}^{2}{ }^{\circ} \mathrm{C}\right)\end{array}$ & $\begin{array}{c}h_{c, \text { avg }} \\
\left(\mathrm{W} / \mathrm{m}^{2}{ }^{\circ} \mathrm{C}\right)\end{array}$ & $\begin{array}{c}h_{e} \\
\left(\mathrm{~W} / \mathrm{m}^{20} \mathrm{C}\right)\end{array}$ & $\begin{array}{c}h_{e, \text { avg }} \\
\left(\mathrm{W} / \mathrm{m}^{2}{ }^{\circ} \mathrm{C}\right)\end{array}$ \\
\hline 0.98 & 0.31 & $2.45-2.49$ & 2.48 & $28.08-38.73$ & 35.08 \\
\hline
\end{tabular}


From Table 3, it is observed that the rate of moisture removal is faster in the initial stage and decreases with the increase in drying time. The values of convective heat transfer coefficient $\left(h_{c}\right)$ are observed to vary from 2.45 to $2.49 \mathrm{~W} / \mathrm{m}^{2}{ }^{\circ} \mathrm{C}$. Its average value is found to be $2.48 \mathrm{~W} / \mathrm{m}^{2}{ }^{\circ} \mathrm{C}$. Variation of $h_{c}$ with respect to time is illustrated in Fig. 3. It is observed from Fig. 3 that the value of $h_{c}$ does not vary much and is almost constant throughout the experiment. The values of evaporative heat transfer coefficient $\left(h_{e}\right)$ are observed to vary from 28.08 to $38.13 \mathrm{~W} / \mathrm{m}^{2}{ }^{\circ} \mathrm{C}$. The average value of $h_{e}$ for groundnut drying is found to be $35.08 \mathrm{~W} / \mathrm{m}^{2}{ }^{\circ} \mathrm{C}$. The variability in $h_{e}$ is observed to be $37.93 \%$ which is more than the variability in $h_{c}$. The variation of $h_{e}$ with time is shown in Fig. 4. The photographs of groundnut drying before and after drying are shown in Fig. 5. The computed values of experimental error in terms of percent uncertainty (internal + external) are given in Table 5 . The error in the experimental measurements of CHTC and EHTC is shown by the error bar which shows the graphical representation of the variability of data. The variability of CHTC and EHTC from its true value is shown by the error bars, with $95 \%$ confidence level, in Fig. 6 which is drawn with the help of SPSS software (version 24).

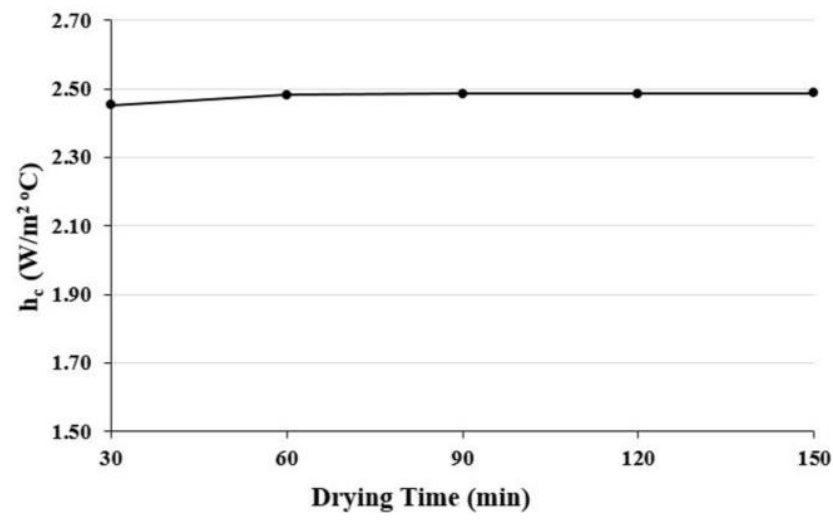

Fig. 3 Variation of $h_{c}$ with time

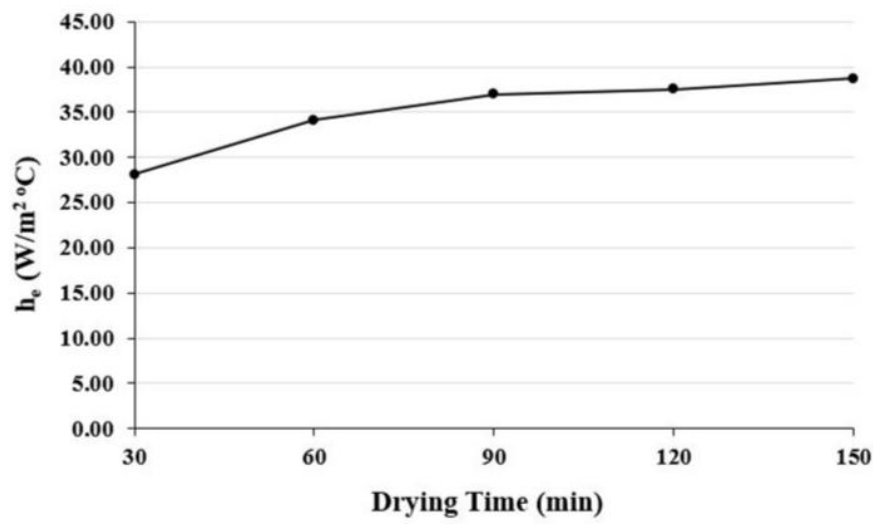

Fig. 4 Variation of $h_{e}$ with time 


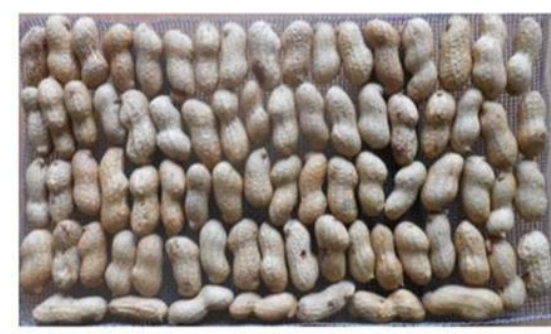

Before drying

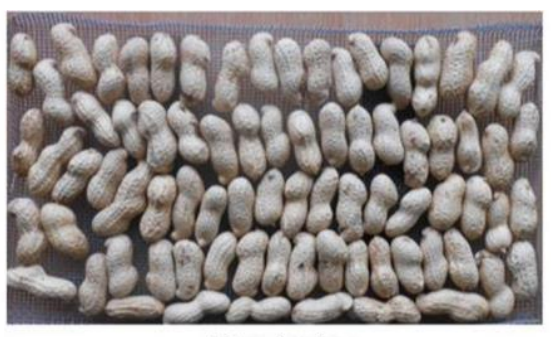

After drying

Fig. 5 Photograph of groundnut sample before and after drying

Table 5 Experimental percent uncertainties for groundnut drying under IFCD mode

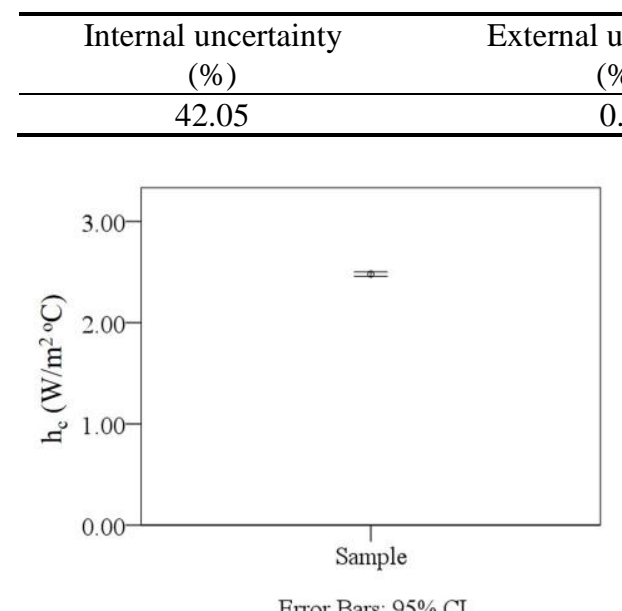

\begin{tabular}{lc}
$\begin{array}{l}\text { l uncertainty } \\
(\%)\end{array}$ & $\begin{array}{c}\text { Total uncertainty } \\
(\%)\end{array}$ \\
\hline 0.5 & 42.55 \\
\hline
\end{tabular}

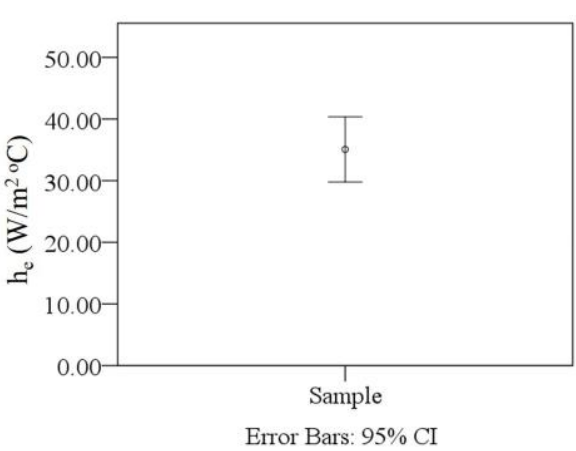

Fig. 6 Error bars for CHTC and EHTC

\section{CONCLUSIONS}

The following conclusions are made from the present study in which convective heat transfer coefficient (CHTC) and evaporative heat transfer coefficient (EHTC) for groundnut drying under indoor forced convection drying (IFCD) mode are evaluated.

1. The value of CHTC for the drying of groundnut drying under IFCD mode is found to vary from 2.45 to $2.49 \mathrm{~W} / \mathrm{m}^{2}{ }^{\circ} \mathrm{C}$. The average value of the $\mathrm{CHTC}$ for the drying of groundnut is observed to be $2.48 \mathrm{~W} / \mathrm{m}^{2}{ }^{\circ} \mathrm{C}$. The CHTC is observed to be almost constant throughout the experiment.

2. The value of EHTC for the drying of groundnuts under IFCD mode is found to vary from 28.08 to $38.73 \mathrm{~W} / \mathrm{m}^{2}{ }^{\circ} \mathrm{C}$. The average value of EHTC for drying of groundnut under IFCD mode is observed to be $35.08 \mathrm{~W} / \mathrm{m}^{2}{ }^{\circ} \mathrm{C}$. The variability of $h_{e}$ is observed to be more than the CHTC. 
3. The experimental error in terms of percent uncertainty (internal + external) for the drying of groundnuts under IFCD mode is computed as $42.55 \%$.

4. This research work will be helpful in designing a better dryer for drying groundnuts to retain their quality during storage so that the farmers in the developing countries can increase the storage life of groundnuts.

\section{REFERENCES}

1. Woodroof, J. G., 1983, Peanut: Production, processing, products, Westport, CT: AVI.

2. Sahdev, R. K., Kumar, M., Dhingra, A. K., 2015, Present status of peanuts and progression in its processing and preservation techniques, Agricultural Engineering International: CIGR Journal, 17(3), pp. 309-327.

3. Arya, S.S., Salve, A.R., Chauhan, S., 2016, Peanuts as functional food: a review, Journal of food science and technology, 53(1), pp. 31-41.

4. USDA, 2015, Foreign Agricultural Service Table 13 Peanut, area, yield and production, online available http://apps.fas.usda.gov/psdonline/psdReport.aspx?hidReportRetrievalName=Table+13+Peanut+Area\%2c+ Yield\%2c+and+Production\&hidReportRetrievalID=918\&hidReportRetrievalTemplateID $=1$ (Last access: March 25, 2016).

5. Agricultural and Processed Food Products Export Development Authority (APEDA), 2016, [online] Available from http://agriexchange.apeda.gov.in/indexp/genReport_combined.aspx\#content (Last access: March 26, 2016)

6. Tiwari, S., Tiwari, G.N., Al-Helal, I. M., 2016, Performance analysis of photovoltaic-thermal (PVT) mixed mode greenhouse solar dryer, Solar Energy, 133, pp. 421-428.

7. Sahdev, R. K., Kumar, M., Dhingra, A.K., 2016, A review on applications of greenhouse drying and its performance, Agricultural Engineering International: CIGR Journal, 18(2), pp. 395-412.

8. Chauhan, P. S., Kumar, A., 2016, Performance analysis of greenhouse dryer by using insulated northwall under natural convection mode, Energy Reports, 2, pp. 107-116.

9. Akpinar, E. K., 2004, Experimental determination of convective heat transfer coefficient of some agricultural products in forced convection drying, International Communications in Heat and Mass Transfer, 31(4), pp. 585-595.

10. Kumar, M., Khatak, P., Sahdev, R. K., Prakash, O., 2011, The effect of open sun and indoor forced convection on heat transfer coefficient for the drying of papad, Journal of Energy in Southern Africa, 22(2), pp. $40-46$.

11. Anwar, S. I., Singh, R. D., 2012, Convective heat transfer coefficient of Indian Gooseberry (Emblica Officinalis) dried in three different forms under forced convection mode, Journal of Engineering Science and Technology, 7(5), pp. $635-645$

12. Sahdev, R. K., Jain, N., Kumar, M., 2012, Convective heat transfer coefficient for indoor forced convection drying of vermicelli, IOSR Journal of Engineering, 2(6), pp. 1282-1290.

13. Sahdev, R. K., Saroha, C. R., Kumar, M., 2013, Convective heat transfer coefficient for indoor forced convection drying of corn kernels, International Journal of Mechanical Engineering and Robotics and Research, 2(4), pp. 18-24.

14. Kumar, M., 2014, Forced Convection Drying of Khoa: A Heat Desiccated Milk Product. Journal of Engineering and Technology, 4(2), pp. 110-114.

15. Ahmed, Ramachar, S. A., D., Allabaksh, M., Rao S. D. T., 1967, Accelerated drying of groundnuts Journal of the Science of Food and Agriculture, 18(3), pp. 116-118.

16. Blankenship, P., Chew, V., 1979, Peanut drying energy consumption, Peanut Science, 6(1), pp. 10-13.

17. Troeger, J. M., Butler, J. L., 1980, Drying of peanuts with intermittent airflow, Transactions of ASAE, 23(1), pp. 197-199.

18. Troeger, J. M., Butler J. L., 1980a, Peanut drying with solar energy, Transactions of the ASAE, 23(5), pp. 1250-1253.

19. Nawungkalatusart, S., Tamtawatchai, C., 1989, Groundnut drying by hot air. In 8. Thailand National Groundnut Meeting, Rio-Et (Thailand), 3-5 May, 1989, pp. 432-436.

20. Premkumar, K., 1990, Study on convection and conduction drying of peanut. Summary Thesis, online available from: http://agris.fao.org/aos/records/TH1998001288?output=xml (Last access: December 7, 2016). 
21. Gowda, D. J., Shivaprasad, V., Ramaiah, H., 1991, Drying and storage studies on Groundnut (DH-330) seeds (Arachis hypogea L.), Karnataka J. Agri. Sci., 4(1-2), pp. 32-35.

22. Noomhorm, A., Premkumar K., Ting, C. C., 1992, Accelerated drying of groundnuts in batch rotary drier, ASEAN Food Journal, 7(3), pp. 159-160.

23. Noomhorm, A., Premakumar K., Sabarez, H. T., 1994, Design and development of a conduction drier for accelerated drying of peanuts, Journal of Food Engineering, 21(4), pp. 411-419.

24. Syarief, A. M., Mugnisjah W. Q., Kuncoro S., Umendong, J., 1996, Drying of peanut seed using free convection type drier, Journal Penelitian Pengembabgan Wilayah Lhan Kering, 17, pp. 1-16.

25. Tumbel, N., Widardo S. H., Harmain E., Kumolontang, N. P., 1997, Testing of groundnut tray dryer. Majalah Ilmiah BIMN, 10, pp. 34-39.

26. Ertas, A., Firenza S., Tanju B. T., Cuvalci O., Maiwall T. T., Schubert M., Henning R., Butts C., 1999 , Design and Development of A new Peanut Curing Process For West-Texas, Drying Technology, 17(6), pp. 1149-1159.

27. Jain, N. K., Kothari S., and Mathur, A. N., 2004, Techno-economic evaluation of forced convection solar dryer, Journal of Agriculture Engineering, 41(3), pp. 6-12.

28. Palacios, T. R., Potes L. B., Montenegro R. A., Sergio, A. G., 2004, Peanut Drying Kinetics: Determination of the effective diffusivity for in-shell and shelled peanuts by applying a short-time analytical model to measured data. Drying 2004 - Proceedings of the 14th International Drying Symposium (IDS 2004), São Paulo, Brazil, 22-25 August 2004, vol. B, pp. 1448-1455.

29. Tarigan, E., Tekasakul, P., 2005, A mixed mode natural convection solar dryer with biomass burner and heat back-up heater, Australia and New Zealand solar energy society, 7(2), pp. 1-10.

30. Ezekoye, B. A., Enebe, O. M., 2006, Development and performance evaluation of modified integrated passive solar grain dryer, The Pacific Journal of Science and Technology, 7(2), pp. 185-190.

31. Ahmed, M., Mirani, A. A., 2012, Heated air drying of groundnut, Pakistan Journal of Agricultural Research, 25(4), pp. 272-279.

32. Mennouche, D., Bouchekima, B., Zibhmi, S., Boubekri, A., Boughali, S., Matallah, A., 2014, An experimental study on the drying of peanuts using indirect solar dryer, International Conference on Clean Energy 2014 Istanbul, Yurkey, June 8-12, 2014.

33. Mennouche, D., Bouchekima, B., Zibhmi, S., Boubekri, A., Boughali S., Matallah, A., 2015, An experimental study on the drying of peanuts using a direct solar dryer. 17èmes Journées Internationales de Thermique (JITH 2015), Marseille (France), 28-30 October, 2015.

34. Kumar, M., 2016, Experimental forced solar thin layer ginger drying, Facta Universitatis, Series: Mechanical Engineering, 14(1), pp.101-111.

35. Kumar, M, Prakash, O, and Kasana, K. S., 2011, Experimental investigation on natural convection heating of milk, Journal of Food Process Engineering, 35(5), pp. 715 - 726.

36. Kumar, M., 2013, Forced convection greenhouse papad drying: an experimental study, Journal of Engineering, Science and Technology, 8(2), pp.177-189.

37. Nakra, B. C., Choudhary, K. K., 1991, Instrumentation, measurement and analysis, Tata Mcgraw-Hill Publishing Co. New Delhi.

38. Holman, J. P., 2004, Heat Transfer, Tata McGraw Hill, New Delhi. 